\title{
RESEARCH
}

Open Access

\section{Results of a randomized controlled trial of level Ilb preserving neck dissection in clinically node-negative squamous carcinoma of the oral cavity}

Manoj Pandey ${ }^{1 *}$ (D), Senniappan Karthikeyan ${ }^{1}$, Deepika Joshi ${ }^{2}$, Mohan Kumar $^{3}$ and Mridula Shukla ${ }^{3,4}$

\begin{abstract}
Background: The lymphatic spread from the cancers of the oral cavity follows an orderly progression and involvement of lower nodes without involvement of upper nodes and skip metastasis is rare. Selective neck dissections are increasingly being performed for node-positive patients; however, in node-negative patients the options of wait and watch, prophylactic radiotherapy, and prophylactic elective node dissections are debated. Quality of life and shoulder functions are important to choose the appropriate therapeutic modality.

Patients and methods: Patients with oral squamous carcinoma with clinically and radiologically negative neck were randomized to Ilb preserving superselective neck dissection or conventional supraomohyoid neck dissection. The primary end point of the study was recurrence of disease (clinical or radiological) and shoulder function as demonstrated by the clinical examination and electromyography. The secondary end point was quality of life as measured by the FACT-HN version 4 questionnaire at the end of 1 year follow-up.

Results: The mean number of lymph node harvested per patient was 25.6 (range 8-85). Of the 32 patients, 3 had histologically positive node in level $\mathrm{lb}$, one of these patients had single positive node while the remaining two had three positive nodes in level Ib. At median follow-up of 36 months disease-free survival in Illb, sparing group was $83 \%$ compared to $91 \%$ in control arm, the difference in survival between two groups was statistically not significant ( $p=0.694)$. EMG of the shoulder showed denervation pattern in $45 \%$ patients undergoing llb preserving surgery at 1 month follow-up compared to $95 \%$ in conventional surgery group, this recovered in all patients but one at 3 months and $100 \%$ recovery was seen at 6 months.

Conclusions: The results of the present study indicate that superselective IIb preserving neck dissections are technically feasible and appear to be oncologically safe procedures when performed as elective prophylactic procedures in highly select group of patients. A significant number of occult metastasis seen in the present study suggests prophylactic dissection to be better than wait and watch policy. Results also show initial higher shoulder morbidity at 1 month in patients undergoing $\mathrm{llb}$ preserving dissections; however, at the end of 1 year recovery is complete and both procedures are comparable.
\end{abstract}

Trial registration: The trial is registered at clinicaltrials.gov with registration no NCT00847717; registered on February 19, 2009.

\footnotetext{
* Correspondence: manojpandey66@gmail.com

${ }^{1}$ Department of Surgical Oncology, Institute of Medical Sciences, Banaras

Hindu University, Varanasi 221005 , India

Full list of author information is available at the end of the article
}

(c) The Author(s). 2018 Open Access This article is distributed under the terms of the Creative Commons Attribution 4.0 International License (http://creativecommons.org/licenses/by/4.0/), which permits unrestricted use, distribution, and reproduction in any medium, provided you give appropriate credit to the original author(s) and the source, provide a link to the Creative Commons license, and indicate if changes were made. The Creative Commons Public Domain Dedication waiver (http://creativecommons.org/publicdomain/zero/1.0/) applies to the data made available in this article, unless otherwise stated. 


\section{Introduction}

Cancer of the oral cavity is the major health problem with over 2,70,000 new cases and 1,45,000 deaths reported worldwide annually [1]. Two third of this global burden is reported from low resource developing countries [2]. The cancer of the oral cavity has high propensity to disseminate along the lymphatics to cervical lymph nodes. Presence of metastatic disease in lymph nodes and extranodal spread are found to be independent predictor of survival [3, 4]. It is reported that patients with higher metastatic nodal burden have poor survival compared to those without nodal disease $[3,4]$.

It has also been reported that lymphatic spread from carcinoma of the oral cavity follows an orderly pattern of progression and risk of skip metastasis to lower nodes is negligible $[5,6]$. With that in mind, the management of neck nodes has evolved considerably since the first report of radical neck dissection by Crile in 1906. Comprehensive functional and conservative neck dissections are routinely performed for neck positive disease; however, the management of clinically and radiologically negative neck is still controversial.

Elective prophylactic conservative neck dissection is practiced widely for node-negative disease due to the fact that neck dissection still remains the most accurate method of neck staging, thereby guiding adjuvant treatment and predicting the outcome [7-9]. Moreover, for malignancies requiring cervicofacial approach for extirpate the tumor, surgeons prefer to do a prophylactic neck dissection, as the neck will be entered anyway.

Wait and watch and delayed neck dissection, as and when the disease develop in neck is an option practiced for mainly the lesions that are excised intra orally [10]. Prophylectic neck irradiation is also practiced but remains controversial. As most resections for oral cancer require a cervicofacial approach with lip split for their excision especially in tobacco chewers with trismus, most of these patients undergo an elective prophylactic neck dissection.

One of the most frequent problems encountered in patients undergoing neck dissection is shoulder dysfunction [11-13]. This dysfunction is mainly due to injury to spinal accessory nerve that crosses level II and splits it into level IIa lying anterior to the nerve and level IIb that lies posterior-medially to the nerve, and nerve need be retracted to clear nodes in this area $[11,12,14]$. The second cause is injury to transverse cervical artery that traverses the level IV. As most node-negative patients undergo conservative neck dissection in form of supraomohyoid dissection arterial injury is usually not a cause for concern. However, the spinal accessory nerve is to be dissected and retracted to clear level IIb nodes that lie posterior to the nerve and hence is most important cause of shoulder dysfunction. As we know that the lymphatic spread follows an orderly pattern and involvement of IIb by skip metastasis is very rare in clinically and radiologically negative neck $[5,6]$, we hypothesized that in this subgroup of patients a IIb sparing neck dissection can safely be carried out. It is further hypothesized that in such a dissection the handling of the spinal accessory nerve is minimized and hence its injury and resulting shoulder dysfunction can be altogether avoided. We report here the results of randomized controlled trial comparing results of superselective IIb preserving neck dissection with comprehensive clearance of level I to III (supraomohyoid neck dissection) in node-negative squamous oral cancer.

\section{Material and methods}

Between December 2007 and August 2009, 32 patients with oral squamous carcinoma with clinically and radiologically negative neck were randomized to IIb preserving superselective neck dissection or conventional supraomohyoid neck dissection. The trial was approved by institute ethics committee and written informed consent was obtained from all study participants. The study was single blinded as the participants did not know in advance as to which treatment will be offered to them, the randomization was done by KS. The inclusion and exclusion criteria were as follows.

\section{Inclusion criteria}

Patients with clinically and radiologically negative neck, histologically proven squamous carcinoma of the oral cavity, over 18 years of age with ability to give consent.

\section{Exclusion criteria}

Patients with synchronous primaries, distant metastasis, previous surgery on neck, previous radiotherapy, history of previous head and neck cancers except basal cell carcinoma, and pregnant and lactating women were excluded.

\section{Preoperative work-up and study design}

Preoperative work-up included a detailed clinical examination followed by radiological evaluation of the neck using computerized tomography (CT) scan, after the biopsy confirmation of the primary tumor. Preoperative shoulder function was evaluated by a detailed clinical examination demonstrating range of shoulder abduction and flexion with goniometry and electromyography of the trapezius muscle. Quality of life was measured using FACT-HN version 4 questionnaire in native Hindi language. 


\section{Operative procedures}

In the control arm, a standard conservative neck dissection (supra omohyoid neck dissection) was carried out. After the dissection, all nodal stations were labeled separately and were sent for histopathology. In the treatment arm, the dissection in level II was stopped at the level of spinal accessory nerve. All the content of level IIb that lies posterior to the nerve was left undisturbed. All nodal stations were labeled before being sent for histopathology.

\section{Postoperative course and follow-up}

Postoperative radiotherapy was given to patients with positive or close margin of excision of primary, T3 or T4 primary tumor, histologically positive lymph nodes or extracapsular spread if present or any other poor prognostic marker in primary like lymphovascular or perineural invasion. Patients were placed on regular monthly follow-up.

The primary end point of the study was recurrence of disease (clinical or radiological) and shoulder function as demonstrated by the clinical examination and electromyography. The secondary end point was quality of life as measured by the FACT-HN version 4 questionnaire at the end of 1 year follow-up.

At 1, 3, 6, and 12 months interval patients were evaluated by ultrasonography of the neck, evaluation of the shoulder function by clinical examination demonstrating range of movement by goniometry and EMG of trapezius muscle. At each of this evaluation, the quality of life was also recorded. Statistical analysis was carried out using Mann-Whitney $U$ test, one-way ANOVA, and paired $t$ test.

\section{Results}

Of the 32 patients recruited, 12 (37.5\%) were randomized to level IIb sparing neck dissection while 20 (62.5\%) were randomized to control using computer-generated randomization. The patients' characteristics of two groups are detailed in Table 1. The mean number of lymph node harvested per patient was 25.6 (range 885). The average number of nodes harvested per level in two groups is detailed in Table 2, while Table 3 describes the lymph node ratio (percentage). There was no statistical difference in the number of nodes harvested in two groups, and lymph node ratio was less than $5 \%$ in both groups. Of the 32 patients, 3 had histologically positive node, two of these patients had single positive node while the remaining had three positive nodes in.

\section{Loco-regional failure}

Three patients had loco-regional failure in IIb sparing group. The failure occurred at primary site within a month of surgery in one of the patient despite a
Table 1 Patient characteristics

\begin{tabular}{|c|c|c|c|c|}
\hline Variable & Sub group & 2b sparing & Control & $P$ value \\
\hline \multirow[t]{2}{*}{ Gender } & Male & 10 & 18 & 0.6 \\
\hline & Female & 2 & 2 & \\
\hline \multirow[t]{3}{*}{ Primary site } & Buccal mucosa & 8 & 10 & 0.15 \\
\hline & Lower alveolus & 0 & 6 & \\
\hline & tongue & 4 & 4 & \\
\hline Premalignant lesion & Leukoplakia & 4 & 4 & 0.43 \\
\hline \multirow[t]{2}{*}{ Habits } & Tobacco chewing & 8 & 17 & 0.16 \\
\hline & Chewing + smoking & 2 & 3 & \\
\hline \multirow[t]{4}{*}{ Clinical T stage } & cT2 & 9 & 12 & 0.301 \\
\hline & cT3 & 2 & 2 & \\
\hline & cT4 & 0 & 5 & \\
\hline & cTx & 1 & 1 & \\
\hline \multirow[t]{4}{*}{ TNM stage } & I & 1 & 1 & 0.234 \\
\hline & $\|$ & 8 & 12 & \\
\hline & III & 3 & 2 & \\
\hline & IV & 0 & 5 & \\
\hline $\begin{array}{l}\text { Surgery } \\
\text { for primary }\end{array}$ & WLE & 12 & 20 & \\
\hline \multirow[t]{4}{*}{ Bone resection } & $\begin{array}{l}\text { Hemi } \\
\text { mandibulectomy }\end{array}$ & 0 & 7 & 0.08 \\
\hline & $\begin{array}{l}\text { Marginal } \\
\text { mandibulectomy }\end{array}$ & 0 & 1 & \\
\hline & $\begin{array}{l}\text { Segmental } \\
\text { mandibulectomy }\end{array}$ & 0 & 2 & \\
\hline & Upper alveolectomy & 1 & 0 & \\
\hline \multirow[t]{3}{*}{ Reconstruction } & Nasolabial & 1 & 4 & 0.5 \\
\hline & Sternomastoid & 2 & 2 & \\
\hline & SSG & 3 & 2 & \\
\hline \multirow[t]{2}{*}{ Neck dissection } & $|-|||$ & 11 & 19 & \\
\hline & I-V & 1 & 1 & \\
\hline \multirow[t]{5}{*}{ Pathological T } & pT1 & 5 & 5 & 0.45 \\
\hline & pT2 & 4 & 7 & \\
\hline & pT3 & 1 & 1 & \\
\hline & pT4 & 1 & 6 & \\
\hline & pTx & 1 & 1 & \\
\hline \multirow[t]{3}{*}{ Margin } & Close & 3 & 4 & 0.5 \\
\hline & Negative & 6 & 10 & \\
\hline & Positive & 3 & 6 & \\
\hline $\begin{array}{l}\text { Lymphovascular } \\
\text { invasion }\end{array}$ & Present & 2 & 7 & 0.263 \\
\hline Perineural invasion & Present & 0 & 4 & 0.12 \\
\hline Radiotherapy & Yes & 2 & 11 & 0.05 \\
\hline Chemotherapy & Yes & 3 & 3 & 0.6 \\
\hline Recurrences & Yes & 1 & 2 & 0.6 \\
\hline
\end{tabular}


Table $\mathbf{2}$ Lymph node harvest

\begin{tabular}{|c|c|c|c|c|c|}
\hline \multirow[t]{2}{*}{ Level } & \multicolumn{2}{|c|}{ Ilb preserving } & \multicolumn{2}{|l|}{ Control } & \multirow[t]{2}{*}{$P$ value } \\
\hline & Mean $(n)$ & $\overline{S D}$ & Mean $(n)$ & $\overline{\mathrm{SD}}$ & \\
\hline la & 3 & 1.4 & 3.1 & 2.1 & 0.88 \\
\hline $\mathrm{Ib}$ & 5.5 & 2.9 & 4.7 & 2.6 & 0.459 \\
\hline lla & 7.6 & 8.4 & 7.1 & 7.5 & 0.84 \\
\hline $\mathrm{llb}$ & - & - & 6.1 & 4.9 & - \\
\hline III & 4.3 & 3.3 & 5.7 & 3.8 & 0.29 \\
\hline
\end{tabular}

negative margin. This patient was treated with reexcision and concomitant chemo radiation and is disease-free at 118 months, while another developed a second primary after 98 months. The third recurrence occurred at 32 months and was treated with palliative chemotherapy, the patient died 4 months later. In the control group too there were three failures, one in primary site, one in neck, and the third patient had local recurrence with lung metastasis at 65 months. The patient with neck failure had multiple nodes in level II and III at 6 months of follow-up and was salvaged with a comprehensive neck dissection and is still alive at 118 months disease-free. One patient with local recurrence was salvaged with surgery and radiotherapy, and is also alive and disease-free, the third patient with metastasis died after 7 months.

At median follow-up of 36 months, the disease-free survival in IIb sparing group was $83 \%$ compared to 91\% in control arm, the difference in survival between two groups was statistically not significant $(p=0.694)$.

\section{Shoulder function}

The results of the shoulder function are detailed in Table 4. The results show significant restriction in shoulder abduction in control group at 1,3 , and 6 months of follow-up; however, the movements were comparable at 1 year. No difference in shoulder flexion was observed in either group.

Table 3 Lymph node ratio

\begin{tabular}{|c|c|c|c|c|c|c|}
\hline \multirow[t]{2}{*}{ Level } & \multicolumn{3}{|l|}{ Ilb sparing } & \multicolumn{3}{|c|}{ Control group } \\
\hline & Harvested & Positive & Ratio (\%) & Harvested & Positive & Ratio (\%) \\
\hline Level la & 36 & 0 & 0 & 62 & 0 & 0 \\
\hline Level lb & 66 & 1 & 1.5 & 95 & 3 & 3.1 \\
\hline Level Ila & 92 & 1 & 1 & 142 & 0 & 0 \\
\hline Level Ilb & - & - & - & 123 & 0 & 0 \\
\hline Level III & 52 & 0 & 0 & 115 & 0 & 0 \\
\hline Total & 259 & $2^{*}$ & 0.77 & 561 & $3^{*}$ & 0.53 \\
\hline
\end{tabular}

*All patients were clinically N0, and only 3 patients had 5 positive nodes

\section{Electromyography}

EMG of the shoulder showed denervation pattern in $45 \%$ patients undergoing IIb preserving surgery at 1 month follow-up, this recovered in all patients but one at 3 months and 100\% recovery was seen at 6 months. In the control group, denervation was seen in $95 \%$ patients at 1 month that showed full recovery at the end of 1 year except for one patient who kept showing denervation pattern (Table 5).

\section{Quality of life}

No significant difference in quality of life was observed in two groups; however, patients undergoing IIb preserving dissections had better general well-being, physical well-being, head- and neck-specific scores, and total FACT-HN scores at 6 months of follow-up (Table 6).

\section{Discussion}

Node-negative oral cancer has perplexed surgeons and oncologist. With improvements in radio diagnosis and guided cytology technique coupled with studies detailing geographical distribution of neck nodes showing rarity of skip metastasis and the knowledge that elective dissection at the time of recurrence does not alter survival has made researchers think in terms of superselective neck dissections.

The results of the present study indicate that superselective IIb preserving neck dissections are technically feasible and oncologically safe procedures when performed as elective prophylactic procedures in select group of patients. Many other studies too have shown similar disease control and survival with selective or super selective neck dissections even in node-positive disease [7, 15-23].

The shoulder morbidity is one of the major concerns for prophylactic dissections [11-13]. Our results indicate significant shoulder abduction morbidity in patients undergoing classical conservative neck dissections. The results are supported by the EMG that showed denervation in $95 \%$ of the patients in this group. However, these morbidity recover with active physiotherapy within 1 year. No difference in shoulder flexion was observed in either group. Hence, in long term, there is no difference observed in shoulder function in either IIb sparing or classical conservative selective neck dissections. Similarly, the quality of life results also show no difference in quality of life in these patients again indicating no significant effect on shoulder function. Chan et al. [11] too have shown that the shoulder impairment is not significantly deranged at 1 year of follow-up. Lee et al. [24] suggested intraoperative monitoring to preserve the spinal accessory nerve; however, the present 
Table 4 Function

\begin{tabular}{|c|c|c|c|c|c|c|}
\hline & \multicolumn{2}{|c|}{ Ilb sparing } & \multicolumn{2}{|c|}{ Full dissection } & \multirow{2}{*}{$\begin{array}{l}\text { Mann-Whitney } \\
U \text { test }\end{array}$} & \multirow[t]{2}{*}{$p$ value } \\
\hline & $\bar{n}$ & Mean \pm SD & $\bar{n}$ & Mean \pm SD & & \\
\hline \multicolumn{7}{|c|}{ Shoulder abduction } \\
\hline Preop & 12 & $160.54 \pm 5.14$ & 20 & $162.10 \pm 5.17$ & 86.500 & 0.330 \\
\hline 1 month & 12 & $146.36 \pm 14.05$ & 20 & $132.90 \pm 12.08$ & 54.000 & 0.020 \\
\hline 3 months & 2 & $151.54 \pm 10.51$ & 19 & $139.57 \pm 10.68$ & 32.500 & 0.009 \\
\hline 6 months & 9 & $155.86 \pm 3.84$ & 16 & $146.62 \pm 9.08$ & 20.000 & 0.016 \\
\hline 12 months & 7 & $156.66 \pm 4.16$ & 8 & $152.37 \pm 6.75$ & 7.000 & 0.304 \\
\hline 18 months & 3 & $157 \pm 0.00$ & 1 & $160 \pm 0.00$ & & \\
\hline \multicolumn{7}{|c|}{ Shoulder flexion } \\
\hline Preop & 12 & $139.18 \pm 4.46$ & 20 & $140.30 \pm 3.59$ & 94.000 & 0.504 \\
\hline 1 month & 12 & $133.45 \pm 6.45$ & 20 & $130.85 \pm 6.06$ & 76.500 & 0.162 \\
\hline 3 months & 2 & $133.33 \pm 5.56$ & 19 & $132.94 \pm 4.39$ & 75.500 & 0.621 \\
\hline 6 months & 9 & $136.71 \pm 4.49$ & 16 & $134.87 \pm 3.63$ & 41.500 & 0.328 \\
\hline 12 months & 7 & $135.66 \pm 3.21$ & 8 & $134.87 \pm 4.54$ & 10.500 & 0.756 \\
\hline 18 months & 3 & $140 \pm 0.00$ & 1 & $132 \pm 0.00$ & & \\
\hline
\end{tabular}

Data in bold are significant $P$ values

Table 5 EMG

\begin{tabular}{|c|c|c|c|c|}
\hline Time & & 2b sparing & Control & $p$ value \\
\hline Pretreatment & Normal & 12 & 20 & \\
\hline \multirow[t]{4}{*}{ At 1 month } & Normal & 2 & 5 & 0.349 \\
\hline & Mild & 5 & 4 & \\
\hline & Moderate & 3 & 10 & \\
\hline & severe & 2 & 1 & \\
\hline \multirow[t]{4}{*}{ At 3 months } & Normal & 6 & 10 & 0.538 \\
\hline & Mild & 3 & 4 & \\
\hline & Moderate & 1 & 5 & \\
\hline & severe & 2 & 1 & \\
\hline \multirow[t]{4}{*}{ At 6 months } & Normal & 9 & 16 & 0.07 \\
\hline & Mild & 0 & 4 & \\
\hline & Moderate & 2 & 0 & \\
\hline & severe & 1 & 0 & \\
\hline \multirow[t]{4}{*}{ At 12 months } & Normal & 9 & 19 & 0.03 \\
\hline & Mild & 3 & 1 & \\
\hline & Moderate & 0 & 0 & \\
\hline & severe & 0 & 0 & \\
\hline \multirow[t]{4}{*}{ At 18 months } & Normal & 11 & 20 & - \\
\hline & Mild & 1 & 0 & \\
\hline & Moderate & 0 & 0 & \\
\hline & severe & 0 & 0 & \\
\hline
\end{tabular}




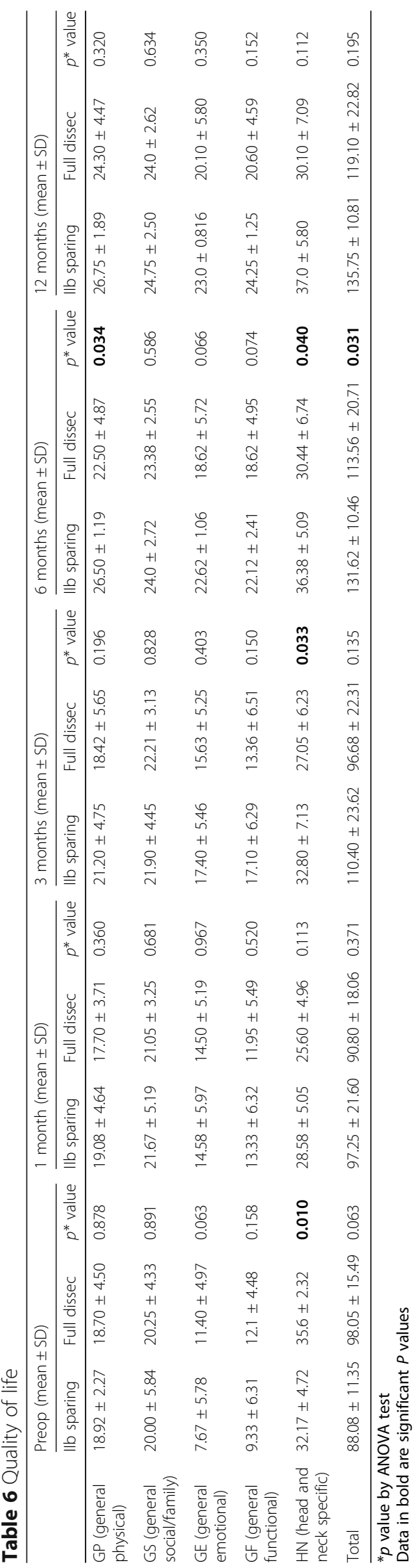


study indicate that this might not be necessary as the function after super selective neck dissections recovers to normal within 3 months of surgery. Similar results have also been reported by Goldstein et al. [13] who also showed improvement of shoulder function over time after conservative neck dissections. Giardiano et al. [12] showed significantly higher early shoulder morbidity with IIb dissections similar to our study; however, longer follow-up was not available in their series.

This is the first randomized controlled trial comparing the two conservative procedures in node-negative neck, though the sample size and inclusion of multiple sites is a limitation, warranting confirmation of results in further multicentric trial to validate the present results in different settings and different primary sites.

\section{Conclusion}

The results of the present study indicate that super selective IIb sparing neck dissection is oncologically safe procedure with lower morbidity in node-negative squamous oral carcinoma patients. The procedure has no shoulder morbidity, and if the morbidity does occur, the recovery is much faster than the conventional selective neck dissection.

\author{
Acknowledgements \\ None. \\ Funding \\ None.
}

Availability of data and materials

The blinded data will be made available on request.

\section{Disclosure of results before publication}

The results have not been presented or published before.

\section{Authors' contributions}

MP designed and conceived the study, edited the draft manuscript, and approved the final manuscript for publication. SK carried out the study, did the literature search, and prepared the draft manuscript. DJ carried out the neurological examination, performed the neuromuscular tests, and helped with the preparation of the manuscript. MK carried out the pathological examination of the specimen, serial sectioning of harvested lymphnodes, and helped in preparing the manuscript and editing it for intellectual content. MS carried out the pathological examination of the specimen, serial sectioning of harvested lymphnodes, did the literature search, and prepared the manuscript with SK. All authors read and approved the final manuscript.

\section{Ethics approval and consent to participate}

The study was approved by the Institute Ethics committee of Institute of Medical Sciences, Banaras Hindu University, Varanasi, and informed consent was obtained from each of the individual participant.

\section{Consent for publication}

Not applicable.

\section{Competing interests}

The authors declare that they have no competing interests.

\section{Publisher's Note}

Springer Nature remains neutral with regard to jurisdictional claims in published maps and institutional affiliations.

\section{Author details}

'Department of Surgical Oncology, Institute of Medical Sciences, Banaras Hindu University, Varanasi 221 005, India. ${ }^{2}$ Department of Neurology, Institute of Medical Sciences, Banaras Hindu University, Varanasi 221 005, India. ${ }^{3}$ Department of Pathology, Institute of Medical Sciences, Banaras Hindu University, Varanasi 221 005, India. ${ }^{4}$ SRL Religere, Lanka, Varanasi 221005, India.

Received: 6 August 2018 Accepted: 24 October 2018

Published online: 08 November 2018

\section{References}

1. Masamatti SS, Gosavi AV. Histopathological study of malignant oral tumours: a five-year study. Int J Sci Study. 2016;4(3):30-4.

2. Gupta B, Ariyawardana A, Johnson NW. Oral cancer in India continues in epidemic proportions: evidence base and policy initiatives. Int Dent J. 2013; 63(1):12-25

3. Imre A, Pinar E, Dincer E, Ozkul Y, Aslan H, Songu M, et al. Lymph node density in node-positive laryngeal carcinoma: analysis of prognostic value for survival. Otolaryngol Head Neck Surg. 2016. https://doi.org/10.1177/ 0194599816652371.

4. Yildiz MM, Petersen I, Eigendorff E, Schlattmann P, Guntinas-Lichius O. Which is the most suitable lymph node predictor for overall survival after primary surgery of head and neck cancer: $\mathrm{pN}$, the number or the ratio of positive lymph nodes, or log odds? J Cancer Res Clin Oncol. 2016;142(4): 885-93.

5. Pandey M, Shukla M, Nithya CS. Pattern of lymphatic spread from carcinoma of the buccal mucosa and its implication for less than radical surgery. J Oral Maxillofac Surg. 2011;69(2):340-5.

6. Nithya C, Pandey M, Naik B, Ahamed IM. Patterns of cervical metastasis from carcinoma of the oral tongue. World J Surg Oncol. 2003;1(1):10.

7. Barzan L, Talamini R, Franchin G, Pin M, Silvestrini M, Grando G, et al. Effectiveness of selective neck dissection in head and neck cancer: the experience of two Italian centers. Laryngoscope. 2015;125(8):1849-55.

8. Hamoir M, Schmitz S, Gregoire V. The role of neck dissection in squamous cell carcinoma of the head and neck. Curr Treat Options in Oncol. 2014; 15(4):611-24.

9. Mirea D, Grigore R, Safta D, Mirea L, Popescu C, Popescu B, et al. Elective neck dissection in patients with stage T1-T2NO carcinoma of the anterior tongue. Hippokratia. 2014;18(2):120-4.

10. Dik EA, Willems SM, Ipenburg NA, Rosenberg AJ, Van Cann EM, van Es RJ. Watchful waiting of the neck in early stage oral cancer is unfavourable for patients with occult nodal disease. Int J Oral Maxillofac Surg. 2016;45(8):945-50.

11. Chan JY, Wong ST, Chan RC, Wei WI. Shoulder dysfunction after selective neck dissection in recurrent nasopharyngeal carcinoma. Otolaryngol Head Neck Surg. 2015;153(3):379-84.

12. Giordano L, Sarandria D, Fabiano B, Del CU, Bussi M. Shoulder function after selective and superselective neck dissections: clinical and functional outcomes. Acta Otorhinolaryngol Ital. 2012;32(6):376-9.

13. Goldstein DP, Ringash J, Bissada E, Jaquet $Y$, Irish J, Chepeha D, et al. Scoping review of the literature on shoulder impairments and disability after neck dissection. Head Neck. 2014;36(2):299-308.

14. Sheikh A, Shallwani H, Ghaffar S. Postoperative shoulder function after different types of neck dissection in head and neck cancer. Ear Nose Throat J. 2014;93(4-5):E21-6.

15. Balasundram S, Mustafa WM, Ip J, Adnan TH, Supramaniam P. Conservative neck dissection in oral cancer patients: a 5 year retrospective study in Malaysia. Asian Pac J Cancer Prev. 2012;13(8):4045-50.

16. Battoo AJ, Hedne N, Ahmad SZ, Thankappan K, lyer S, Kuriakose MA. Selective neck dissection is effective in N1/N2 nodal stage oral cavity squamous cell carcinoma. J Oral Maxillofac Surg. 2013;71(3):636-43.

17. Bier J, Schlums D, Metelmann H, Howaldt HP, Pitz H. A comparison of radical and conservative neck dissection. Int J Oral Maxillofac Surg. 1993; 22(2):102-7.

18. Bier J. Radical neck dissection versus conservative neck dissection for squamous cell carcinoma of the oral cavity. Recent Results Cancer Res. 1994;134:57-62.

19. Bocca E. Conservative neck dissection. Laryngoscope. 1975;85(9):1511-5. 
20. Dragan AD, Nixon IJ, Guerrero-Urbano MT, Oakley R, Jeannon JP, Simo R. Selective neck dissection as a therapeutic option in management of squamous cell carcinoma of unknown primary. Eur Arch Otorhinolaryngol. 2014:271(5):1249-56.

21. Elsheikh MN, Mahfouz ME, Salim El, Elsheikh EA. Molecular assessment of neck dissections supports preserving level IIB lymph nodes in selective neck dissection for laryngeal squamous cell carcinoma with a clinically negative neck. ORL J Otorhinolaryngol Relat Spec. 2006;68(3):177-84.

22. Feng Z, Gao Y, Niu LX, Peng X, Guo CB. Selective versus comprehensive neck dissection in the treatment of patients with a pathologically nodepositive neck with or without microscopic extracapsular spread in oral squamous cell carcinoma. Int J Oral Maxillofac Surg. 2014;43(10):1182-8.

23. Ghantous Y, Akrish S, Abd-Elraziq M, El-Naaj IA. Level IIB neck dissection in oral squamous cell carcinoma: science or myth? J Craniofac Surg. 2016;27(4):1035-40

24. Lee $\mathrm{CH}$, Huang NC, Chen HC, Chen MK. Minimizing shoulder syndrome with intra-operative spinal accessory nerve monitoring for neck dissection. Acta Otorhinolaryngol Ital. 2013;33(2):93-6.

Ready to submit your research? Choose BMC and benefit from:

- fast, convenient online submission

- thorough peer review by experienced researchers in your field

- rapid publication on acceptance

- support for research data, including large and complex data types

- gold Open Access which fosters wider collaboration and increased citations

- maximum visibility for your research: over $100 \mathrm{M}$ website views per year

At $\mathrm{BMC}$, research is always in progress.

Learn more biomedcentral.com/submissions 